\title{
Physicochemical, antioxidant and sensory properties of chocolate spread fortified with jackfruit (Artocarpus heterophyllus) flour
}

\author{
${ }^{1, *}$ Fitriani Nur, U.A., ${ }^{2}$ Yusuf, M., ${ }^{2}$ Pirman, ${ }^{1}$ Syahriati and ${ }^{2}$ Rahmiah, S. \\ ${ }^{I}$ Department of Agroindustry, Politeknik Pertanian Negeri Pangkep, Jl. Poros Makassar - Parepare KM. 83 \\ Mandalle, 90655, Pangkep Regency, Indonesia \\ ${ }^{2}$ Department of Chemical Engineering, Politeknik Negeri Ujung Pandang, Jl. Perintis Kemerdekaan KM. 10 \\ Tamalanrea, 90245, Makassar City, Indonesia
}

\author{
Article history: \\ Received: 2 June 2020 \\ Received in revised form: 9 \\ July 2020 \\ Accepted: 29 July 2020 \\ Available Online: 14 \\ September 2020
}

\section{Keywords:}

Chocolate spread,

Fortified,

Jackfruit,

Physicochemical,

Sensory

DOI:

https://doi.org/10.26656/fr.2017.4(6).262

\begin{abstract}
Chocolate spread is often considered as an unhealthy product with low antioxidant activity and phenolic content since it does not contain cocoa liquor. This research aimed to investigate the potential on the physicochemical composition and antioxidant activity of jackfruit (Artocarpus heterophyllus) flour and red palm olein in the chocolate spread formulations. The effect of the jack fruit and red palm olein incorporation on the quality attributes and high nutritional value of chocolate spread was also examined. Physicochemical properties of the fortified chocolate spread, as well as the evaluation of physical parameters in the chocolate spread, were investigated. Melting points were analyzed by DSC (Differential scanning calorimeter) method, colour lightness was analyzed by chromameter hunter method, profile bioactive compound was analyzed by gas chromatography-mass spectrometry (GC-MS), and whilst for viscosity by Brookfield Viscometer method. The analysis results obtained that the sample code F5 (10\% jackfruit flour: $26 \%$ sugar) contains of $43.47 \%$ fat, $0,88 \%$ free fatty acids, polyphenol $127 \mathrm{mg} / \mathrm{g}$, $160.16 \mathrm{mg} / \mathrm{g}$ carotenoids, $42.75 \mu \mathrm{g} / \mathrm{mL}$ antioxidant activity $\mathrm{IC}_{50}$, and 6.19 degree of acidity per $100 \mathrm{~g}$ chocolate spreads and high panelists preference. However, the fortified chocolate spread had different characteristics from each other either in the chemical, physical or sensory properties. The best formulation code is F5 with $10 \%$ jackfruit flour, fortification significantly increased the antioxidant activity, carotenoid, polyphenols, viscosity, colour and melting points. Additionally, chocolate spread with $10 \%$ of jackfruit flour by-product presented the highest-ranking test rate of the three sensory attributes of aroma, taste and texture. Therefore, the use of jackfruit by-products in the development of chocolate spread is a viable alternative which can be explored for nutritional, technological and sensory purposes by the food industry.
\end{abstract}

\section{Introduction}

The production of fruits like nectars, pulps, sweets, jams, and minimally processed products has been growing and expansion of the processed food market. The current lifestyle is related to the high demand for these products, which requires convenient products and highly practical. Nevertheless, concomitant to the search for processed foods, the production of residues discarded by the industries increased, which might result in environmental damages and rise in costs for the industries (de Toledo et al., 2017)._Jackfruit is the largest known edible fruit whose unutilized, accounts for $60 \%$ of the entire fruit parts include the fibre, peels, and the core. Content macronutrients and bioactive compounds are excellent sources that can be obtained at the edible pulp and seeds of ripe jackfruits (Adan et al., 2020). Jackfruit rich in fibre, carotene, potassium, carbohydrate, lysine, phenylalanine and amino acid leucine was the highest compositions and most abundant amino acid found in jackfruit flour (Zuwariah et al., 2018; $\mathrm{Ng}$ et al., 2019). There is however lack of reference and research available on the antioxidant activity and chemical composition of the peel, fibre and core of ripe jackfruits. Most studies on the jackfruit phytochemical, antioxidant properties and mineral analysis have focused on the edible regions (pulp and seeds) (Adan et al., 2020).

Palm oil is one of the seventeen major oils and fats that are produced and traded worldwide. The extracted 
crude palm oil is fluid at a tropical temperature and has a deep orange-red colour, contributed by a high carotene content. Accordingly, palm oil is a natural resource with high carotene (500-1500 ppm) and tocols (700-1000 ppm) (Mayamol et al., 2007; El-Hadad et al., 2011). The crude palm oil is refined physically or chemically to remove undesirable impurities and produce refined, bleached and deodorized palm oil (RBDPO), which can be fractionated into palm stearin and palm olein (Gee, 2007). As a result, the final product will provide a golden colour but will reduce the content of carotene and tocols (Al-Saqer et al., 2004). Carotene content of red palm olein (RPOL) has a high bioavailability compared to all plants with the same carotene content. RPOL is widely marketed in supermarkets and food stores, in the form of a pro-vitamin A carotenes which work very well for children who are whistly deficient in vitamin A (ElHadad et al., 2011). Research on red palm oil in the form of low doses can avoid and protect children from the malnourished vitamin A deficiency and the risk of going blind. Other functions of carotene are as antioxidant activity, enhancing immune and anti-cancer activity (Sundram, 2005).

Research and analysis of the development of chocolate spread into food functional has been done by some researchers. Research Jeyarani et al. (2013) reported enriched chocolate spreads using soybean and coconut oils to increase the content of omega-3 fatty acids (linoleic and linolenic acid). Formulating chocolate spreads with the addition of red palm olein and butter-fat blends to enhance physicochemical characteristics of phytonutrient (Prasanth Kumar et al., 2016). Study of the manufacture of low-fat chocolate spreads using palm oil, palm kernel fat and their blends (Manzocco et al., 2014). Research on the use of gelatin from the poultry industry in the fat replacement of chocolate spread to improve physicochemical properties and texture chocolate spread (Almeida and Lannes, 2017). On the other hand, Fayaz et al. (2017) reported beeswax fortification, propolis and partial substitutes of palm oil in functional chocolate spread (Fayaz et al., 2017). Process optimization in the manufacture of chocolate spread substitution whey protein concentrate, cocoa powder, olive oil and butterfat using response surface methodology (Kumar, 2015).

Research on jackfruit fortification and red palm olein (RPOL) in the manufacture of chocolate spread has never been reported. Jackfruit is suitable for chocolate raw material because it can be processed into the flour with high carbohydrate. Potential jackfruit is of dietary use and is an important source of carbohydrate, protein, fat, minerals, vitamins, and phytochemical contains useful compounds like the flavonoids, sterols and prenylflavones which may have been responsible for nutritional value (Baliga et al., 2011). While RPOL can be a source of tocopherols and tocotrienols and carotenes can be considered as important constituents in replacing the role of butterfat. Nowadays, functional foods are fast becoming a part of everyday life. This study may provide important information on the possibility of jackfruit and red palm olein chocolate spread as an appropriate way for micronutrients fortification and functional food. Therefore, this study was aimed to determine the effects of micronutrients fortification on the chocolate spread characteristics, physical properties, antioxidant activity and to select the best formulated chocolate spread.

\section{Materials and methods}

\subsection{Materials}

The making of jackfruit flour starts with stage separation of seed from the pulp (Figure 1). Seeds were washed using filtered tap water, sliced, and dried in a forced draft oven (Memmert, Germany) at $50^{\circ} \mathrm{C}$ for 12 hrs. The dried samples were milled into flour using a grinder (Toshiba, Japan) (Zuwariah et al., 2018). Red palm olein (RPOL) was kindly secured by organic red palm oil Salmira Nutri Palma Nabati Company, Indonesia. Fermented and non-fermented cocoa beans varieties Forastero (Figure 1) from Soppeng Regency, South Sulawesi, Indonesia. All samples were made of chocolate spread with lecithin from Sigma-Aldrich (St. Louis, Missouri, United States), cocoa butter from Mars Symbioscience Company (Makassar, South Sulawesi, Indonesia), skim milk by NZMP New Zealand, and sugar. All chemicals were of analytical grade, hexane (CAS: 110-54-3), Sodium carbonate (CAS: 497-19-8) and BHT (Butylated Hydroxytoluene) were supplied by Merck Millipore (Burlington, Massachusetts, United States), DPPH (D4313, CAS: 1898-66-4) was from Tokyo Chemical Industry (Tokyo, Japan), Folin Ciocalteaue (109001), while aluminium chloride (254134, CAS: 12125-02-9), sodium nitrate (CAS: 763199-4), Gallic acid (CAS: 149-91-7) and sodium hydroxide (CAS: 1310-73-2) were from Sigma-Aldrich (St. Louis, Missouri, United States).
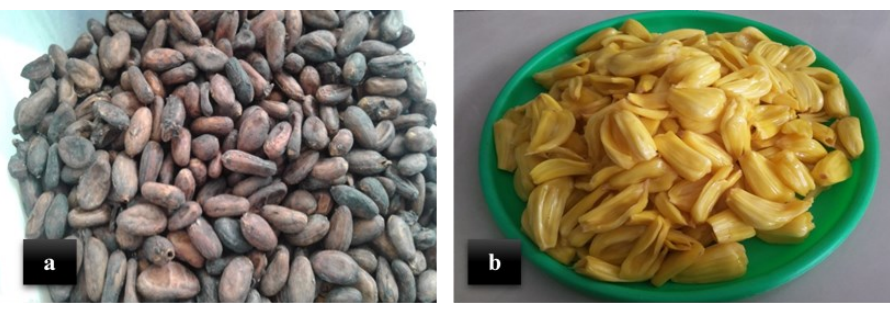

Figure 1. Main ingredient making chocolate spread: a) fermented cocoa beans, and b) jackfruit

Tools water bath (Memmert WNB 7 Basic control) Hettich Zentrifugen EBA-20, rotary evaporator Buchi, Hitachi centrifuge brands, and Shimadzu GC-MS 2010 
brand Gas Chromatography-Mass Spectrometry plus.

\subsection{Chocolate spread production}

Nibs cacao fermented $(60 \%)$ and non-fermented $(40 \%)$ roasted in (roasting machine KL Protech Type Number $043.13 \mathrm{P} 033$ capacity $15 \mathrm{~kg}$ ) at $100-105^{\circ} \mathrm{C}$ for 1 $\mathrm{hr}$, cooling up to reach the temperature $40-50^{\circ} \mathrm{C}$. Then samples of cocoa beans were inserted in winnower (nibs separator machine KL Protech Type Number 049.13P043) to separate between nibs and shell (seeds and outer skin). Once separated from the seeds and outer skin, nibs and shells are weighted, nibs are then ground using a stone mill (KL Protech Type Number 066.13P063) to destroy nibs that initially shaped coarse solid granular into the cocoa paste (cocoa liquor). Furthermore, cocoa liquor and ingredient formulation on Table 1 was taken in a ball mill (ball mill mini KL Protech Type Number 041.,13P028) which is useful to smooth at $50^{\circ} \mathrm{C}, 50 \mathrm{rpm}$ for $12 \mathrm{hrs}$.

Table 1. Chocolates spread formulation

\begin{tabular}{lccccc}
\hline \multirow{2}{*}{$\begin{array}{c}\text { Ingredient } \\
\text { composition }\end{array}$} & \multicolumn{5}{c}{ Samples chocolate spreads (\%) } \\
\cline { 2 - 6 } (control) & F2 & F3 & F4 & F5 \\
\hline Cocoa liquor & 19.5 & 19.5 & 19.5 & 19.5 & 19.5 \\
Red palm olein & 27 & 27 & 27 & 27 & 27 \\
Sugar & 36 & 36 & 36 & 31 & 26 \\
Skim milk & 16.41 & 11.41 & 6.41 & 16.41 & 16.41 \\
Lechitin & 1 & 1 & 1 & 1 & 1 \\
Vanilla & 0.02 & 0.02 & 0.02 & 0.02 & 0.02 \\
Salt & 0.07 & 0.07 & 0.07 & 0.07 & 0.07 \\
Jackfruit flour & 0 & 5 & 10 & 5 & 10 \\
\hline
\end{tabular}

\subsection{Physicochemical analysis of the chocolate spread}

The chocolate spread was analyzed, in duplicate, for free fatty acids, lipids content, carotene content, viscosity (Brookfield viscometer), and analysis $\mathrm{pH}$ using approved methods 940.28-2012, 950.54-1950, 2005.07-2005, 967.16-1968 and 943.02-1943 of the Association of Official Analytical Chemists (AOAC, 2005).

\subsection{DPPH radical scavenging activity}

Analysis antioxidant activity (DPPH scavenging activity) was determined using by modifying the method Sulistyo and Haryanti (2020) the sample was subsequently incubated at room temperature $37^{\circ} \mathrm{C}$ for 30 mins, and the absorbance at $517 \mathrm{~nm}$ was then measured with a spectrophotometer, used synthetic antioxidant BHT (Butylated Hydroxytoluene) as a comparative sample.

\subsection{Colour measurement using hunter method}

Colour analysis of the samples was conducted using Minolta Chroma CR-400 (Minolta Co, Osaka, Japan) and Hunter method (as L, a, and b value) in duplicate with a. The parameter of the value L, a, b sample will be visible, where the value of luminosity (L), Hue angle $\left(^{\circ}\right.$ h) and chromaticity (C) of the chocolate spread surface. The value $(+)$ on a indicates the red colour and the value $(-)$ on a show green colour, the value $(+)$ in the $b$ indicates the yellow colour and the value (-) on the $b$ indicates the blue colour. It is then measured on the chart to know the colour specifications (de Toledo et al., 2017)

\subsection{Melting point analysis}

Melting point determination using DSC/ differential scanning calorimetry, and total phenol content was determined using UV-VIS Shimadzu Japan (UV-1280 UV-Vis Spectrophotometer) with an absorbance of the mixture was measured at $760 \mathrm{~nm}$.

\subsection{Total phenol content}

Total phenol content was expressed as milligram gallic acid equivalent per gram defatted chocolate spread (mg GAE/g DFLA) (Do et al., 2014). Gas chromatography-mass spectrometry (GC-MS) was determined using Shimadzu GC-MS 2010 brand gas chromatography-mass spectrometry plus.

\subsection{Sensory evaluation}

The evaluation using a hedonic ranking test (Friedman test) with parameters texture, taste, and flavour. Panellist $(n=31)$ in the age range of 18-23 consisted of $30 \%$ males, and $70 \%$ of females chosen on the basis that they regularly consumed chocolate spreads. Sensory analyses conducted in the Department of Chemical Engineering Politeknik Negeri Ujung Pandang in panel booths which conform to the International Standards (ISO, 2007), under white light at room temperature. Assessors asked to evaluate the hedonic attributes using a 5-point ranking hedonic scale ranging (1 - like very much, 2 - like moderately, 3 - like slightly, 4 - dislike slightly, 5 - dislike very much).

\section{Results and discussion}

\subsection{Physicochemical and antioxidant activity of} chocolate spreads

The chemical composition of fortified chocolate spread is presented in Table 2. Analysis results showed that total fat content in fortified jackfruit chocolate spread was varying range $40-44 \%$, while free fatty acid range $0.88-0.96 \%$. Carotene concentrations in fortified jackfruit chocolate spread were much higher, highest rate $168.95 \mathrm{mg} / \mathrm{g}$ sample. In contrast to those parameters, jackfruit and red palm olein fortification affected the increased concentration of total fat, free fatty acid, and carotene content. 
Table 2. The colour characteristic of chocolate spread

\begin{tabular}{cccccc}
\hline \multirow{2}{*}{ Parameters } & \multicolumn{5}{c}{ Sample } \\
\cline { 2 - 6 } & F1 & F2 & F3 & F4 & F5 \\
\hline${ }^{*} \mathrm{~L}$ & 18.62 & 19.12 & 19.72 & 20.2 & 19.51 \\
$*_{\mathrm{a}}$ & 2.42 & 2.58 & 2.91 & 2.84 & 3.31 \\
*b $^{\mathrm{y}}$ & 2.99 & 3.03 & 3.6 & 3.7 & 3.79 \\
${ }^{\circ}$ Hue & 3.84 & 3.98 & 4.63 & 4.66 & 5.02 \\
Chromaticity & 51.07 & 49.64 & 51.01 & 52.5 & 48.87 \\
\multirow{2}{*}{ Colour } & Red- & Red- & Red- & Red- & Red- \\
& purple & purple & purple & purple & purple \\
\hline
\end{tabular}

Lipids were the second class of macronutrients with great representativity, compounds which act as the main energy source to the organism. Sample F1 (control) and F2 (5\% jackfruit flour: 36\% sugar) presented the lowest lipid values. Lipids source in the manufacture of chocolate spreads derived from jackfruit flour, red palm olein and cocoa liquor. Jackfruit flour and red palm olein treatments have significant $(\mathrm{p}<0.05)$ effect on the lipids composition of chocolate spread. The effect of lipid type and content on spread physical stability and firmness was assessed by measuring mechanical properties and oil release. An increasing amount of lipids affects the texture of chocolate spread, independently of lipid nature, the increase in fat content was always associated with a decrease in chocolate spread firmness (Manzocco et al., 2014).

Carotenoids, The use of red palm olein to enhance carotenoids in products and imparts a red colour to the oil. Figure 2 shows the carotenoid content of chocolate spread samples. The data shows that the sample F1 (control) has the lowest and F3 (10\% jackfruit flour: $36 \%$ sugar) has the highest amounts of carotenoids content. The carotenoids content increased significantly $(\mathrm{p}<0.05)$ after addition jackfruit flour and red palm olein. Jackfruit flour and red palm olein contributed red colour to the blends. Best chocolate spread formulations by substituting butterfat with 20 to $100 \%$ red palm olein and reported that the product with $20 \%$ replacement was acceptable (El-Hadad et al., 2011). Therefore, synthetic colouring agent can be replaced with the use of Jackfruit flour and red palm olein in various food preparations (Prasanth Kumar et al., 2016). Carotenoids in chocolate spread products range from $122.07-168.95 \mathrm{mg} / \mathrm{g}$ samples. Samples with the addition of $10 \%$ jackfruit flour (sample F3 and F5) tend to be higher compared to samples with the addition of 5\% jackfruit flour (sample F2 and F4) because in jackfruit there is vitamin A in the form of provitamin $A$ that is $\alpha$-carotene, $\beta$-carotene, and $\Upsilon$-carotene, so that with the addition of fruit powder jackfruit can increase the level of carotenoid in the product chocolate spread.

DPPH radical is a stable organic free radical with an absorption band at $517 \mathrm{~nm}$. The results of antioxidant activity show that the sample F5 (10\% jackfruit flour) has the highest DPPH radical scavenging activity and strongest antioxidant activity, by the value $\mathrm{IC}_{50}$ is 42.75 $\mu \mathrm{g} / \mathrm{mL}$, followed by sample F4 (5\% jackfruit flour) 43.70 $\mu \mathrm{g} / \mathrm{mL}$, and sample F5 $48.46 \mu \mathrm{g} / \mathrm{mL}$. As comparison used BHT (Butylated Hydroxytoluene) which has $\mathrm{IC}_{50}$ $7.89 \mu \mathrm{g} / \mathrm{mL}$, data in Figure 2. However, at concentrations ranging from $42.75 \mathrm{mg} / \mathrm{mL}$ to $49.96 \mathrm{mg} / \mathrm{mL}$, its $\mathrm{DPPH}$ radical scavenging activity is significantly different from those of the BHT as comparison sample, studied by Do et al. (2014) a lower $\mathrm{IC}_{50}$ indicates a higher antioxidant activity of a compound. Figure 2 shows the $\mathrm{IC}_{50}$ values in the DPPH radical scavenging activity assay of the sample formulation in scope as the strongest antioxidant.

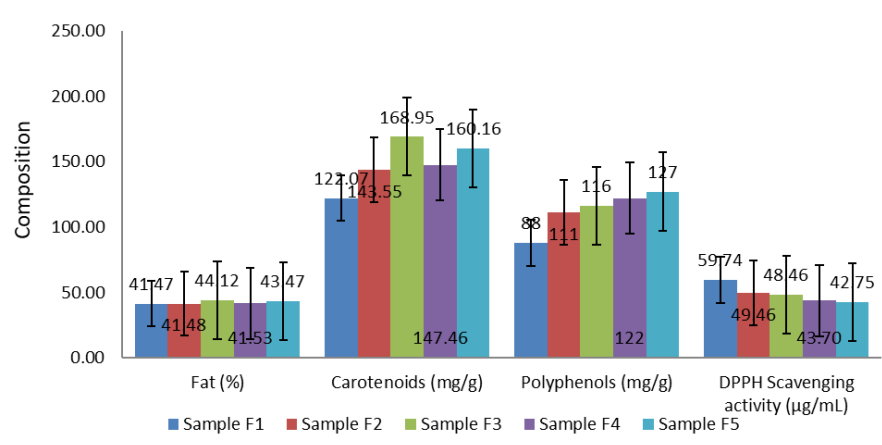

Figure 2. Chocolate spreads composition of fat, carotenoids and DPPH scavenging activity (values were presented as mean $\pm \mathrm{SD}(\mathrm{n}=10,2$ replicates $)$

Finally total polyphenols content. Polyphenols can be found in a wide variety of foodstuffs such as vegetables, tea, coffee, red wine fruit and fruits. According to research, there was found a high positive correlation between phenolic compounds and the number of cocoa solids (Cerit et al., 2016). The total content of polyphenols of all samples is shown in Figure 2. Samples fortified with jackfruit and red palm olein had more polyphenols than the control sample (F1). Better results were obtained with jackfruit flour, even when the addition was in a lower amount than the control sample. Research on fruit fortification was shown that the addition of dried fruits (dried prunes, dried papaya, dried apricots, dried raisins and dried cranberries) especially prunes and cranberries increased the total phenolic content of dark and milk chocolates (Komes et al., 2013). Studied about fortification sea buckthorn and mulberry of dark chocolate also shows the same thing, that the addition of fruit can increase polyphenols levels in the product (Godočiková et al., 2017). Polyphenols increase antioxidant property and reduce human oxidative stress (Loffredo et al., 2018). The concentration of all polyphenols can vary tremendously among different cocoa-containing foods. This concentration can also vary depending on the source of the processing conditions, how the chocolates were 
manufactured and the beans (Godočiková et al., 2017).

Free fatty acids, Figure 3 shows that sample F2 (5\% jackfruit flour: 36\% sugar) and F3 (10\% jackfruit flour: $36 \%$ sugar) comprised the highest amount among all free fatty acids present in the chocolate spreads being around $0.98 \%$ and $0.96 \%$, followed by samples F4, F1 and F5 which ranged from $0.93 \% \%$ to $0.88 \%$. Replacement of butter or cocoa butter by $27 \%$ red palm olein (RPOL) can decrease significantly the free fatty acids. The free fatty acids content decreased significantly $(p>0.05)$ after addition jackfruit flour and substitute cocoa butter with red palm olein. Trans fatty acids in commercial chocolate products including chocolate spread range between $0.7 \%-11.1 \%$. A major source of undesirable trans-fatty acids, since the chocolate spread is consumed by children in a reasonable quantity. The availability of especially fats from palm oil, which are virtually free of trans fatty acids, can be viewed as a healthy alternative.

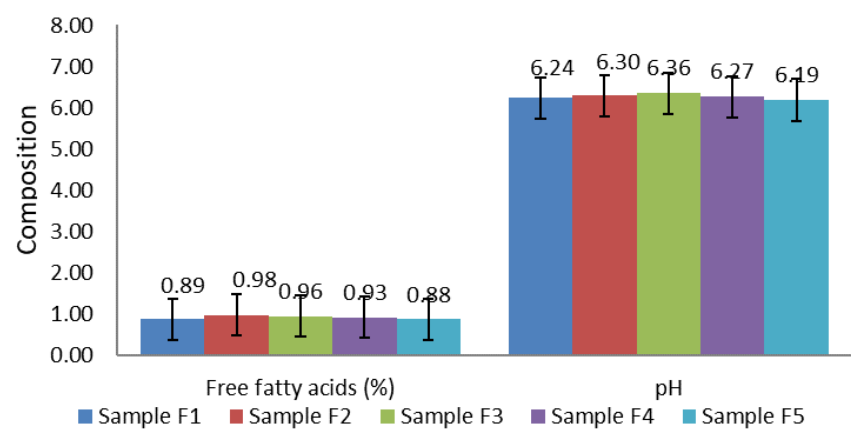

Figure 3. Chocolate spreads composition of free fatty acids and $\mathrm{pH}$ (values were presented as mean $\pm \mathrm{SD}(\mathrm{n}=10,2$ replicates)

Analysis of $\mathrm{pH}, \mathrm{pH}$ of samples differed significantly and ranged from 6.19 to 6.36 (Figure 3). Sample F5 (10\% jackfruit flour: $26 \%$ sugar) had the least $\mathrm{pH}(6.19)$ and sample F3 (10\% jackfruit flour: $36 \%$ sugar) had the highest (6.36). The reference sample (F1) had a $\mathrm{pH}$ value of 6.24 which was not significantly different from sample F3 (10\% jackfruit flour: 36\% sugar) as shown in Figure 3. The addition of jackfruit flours, in general, significantly increased $(\mathrm{p}<0.05)$ the $\mathrm{pH}$ value of the samples. The results of this study are following those obtained research cashew nut-chocolate spread, with $\mathrm{pH}$ values, were higher than 4.90 in the fruit spread produced. Fruits are more acidic than nuts and seeds (such as cocoa and cashew nut) and will, therefore, be the reason for the relatively higher $\mathrm{pH}$ values obtained (Barcelon et al., 2015). Other research has shown that the $\mathrm{pH}$ values of the chocolate spread influence chemical reactions in fermentation cacao, such as Maillard reaction, generating alterations in colour, flavour and texture of the product, parameters related to the perception and sensory acceptance of the consumers (Andrés-Bello et al., 2013).
The viscosity of chocolate spread is a nonNewtonian liquid, and when the visible viscosity $(\mathrm{cP})$ of chocolate formulated with red palm oil is measured, the following trends can be shown. Values of viscosity indicated the presence of a noticeable variation within samples, the apparent viscosity was $8983 \mathrm{cP}$ for the control chocolate spread (F1) and $13932 \mathrm{cP}$ for the sample (F3) in Figure 4. The noticeable variation is a function of the fat replacement effect (Afoakwa et al., 2007). Chocolate is a mixture of solids particles (sugar and cocoa solids) that are hydrophilic and cocoa fats that are finned hydrophobic. The magnitude of viscosity is influenced by several factors such as temperature, the tensile force between molecules, size, and several dissolved molecules. Viscosity difference in a chocolate spread can be caused by the difference in the content of pectin contained in the jackfruit flour. The content of pectin in the fruit during the heating process will undergo gelatination to cause increased viscosity, more addition of jackfruit powder can lead to increased viscosity of chocolate products (Vriesmann et al., 2011).

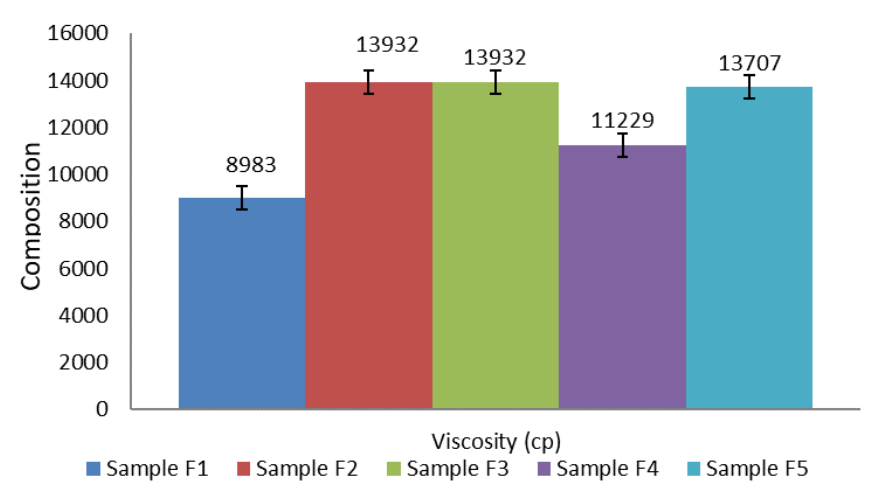

Figure 4. Chocolate spreads composition of viscosity (values were presented as mean $\pm \mathrm{SD}$ ( $\mathrm{n}=10,2$ replicates)

\subsection{Colour analysis of chocolate spread}

The colour characteristic of fortified jackfruit flour chocolate spread is shown in Table 2.

The results show that there is not much difference in the colour lightness, redness and yellow colour components of spreads. The jackfruit flour and red palm olein spread showed a slightly higher brightness than the spreads. The low brightness value of the spreads indicates that the colour features of the spread as dark due to the ingredient used, cocoa liquor, which is dark in colour. The red and yellow colour components showed a slight increase with the increased content of jackfruit flour and red palm olein in spreads. The chocolate spread had a specific colour and melting point. They had redpurple and tended to have low brightness. Micronutrients fortification only gave a slight effect on their colour, where the affected colour parameter was only ${ }^{\circ} \mathrm{Hue}$ value. However, based on their ${ }^{\circ}$ Hue values, the colour 
of fortified chocolate spread was categorized as the same colour, i.e. red-purple (RP). It means that micronutrients fortification did not give a significant effect on colour. The content of carotenoids was correlated well with the red colour components of the blends. The darkness of the chocolate spreads might be preventing the reflectance of the red and yellow colour in the spreads. Hence, all the spreads showed almost similar colour pattern (Prasanth Kumar et al., 2016).

\subsection{Melting point determination of chocolate spread}

Thermal behaviour or melting profile of fat and sugar components in samples produced from different substitution level for jackfruit flour were analyzed by using differential scanning calorimetry (DSC). Peak onset corresponds to the temperature at which a specific crystal form starts to melt; peak maximum, that at which melting rate is greatest; and end of melting, completion of liquefaction (Afoakwa et al., 2008; Amir et al., 2013). Heat capacity $\mathrm{Cp}$ gradually and consistently increased to onset temperature $\left(\mathrm{T}_{\text {onset }}\right)$ then progressively increased more rapidly until peak temperature $\left(\mathrm{T}_{\text {peak }}\right)$, after which it decreased to the end temperature ( $\mathrm{T}_{\text {end }}$ ) indicating the chocolate was completely melted (Amir et al., 2013). The melting profile of jackfruit flour, sugar and red palm olein blends at various temperature ranges are presented in supplementary Figure 5. The melting points of jackfruit flour and red palm olein were within $27.6-$ $30.2^{\circ} \mathrm{C}$. Varying jackfruit flour, sugar and substitution cocoa butter with red palm olein content, observed in the differences in peak widths and produce changes in crystallinity and melting properties (Afoakwa et al., 2008). Increasing fat content caused a consistent decrease in $\mathrm{T}_{\text {index }}$ of products, because chocolate of lower fat content melts at a higher temperature, suggesting an inverse relationship of $T_{\text {index }}$ with fat content. Higher fat contents than similar to lower fat chocolate require a longer time to melt products (Afoakwa et al., 2008).

\subsection{GC-MS analysis of chocolate spread}

The GC and MS running time for profile sample F5 (10\% jackfruit flour: $26 \%$ sugar; $27 \%$ red palm olein) with the best characteristics in terms of physicochemical properties, antioxidant activity and sensory properties. A
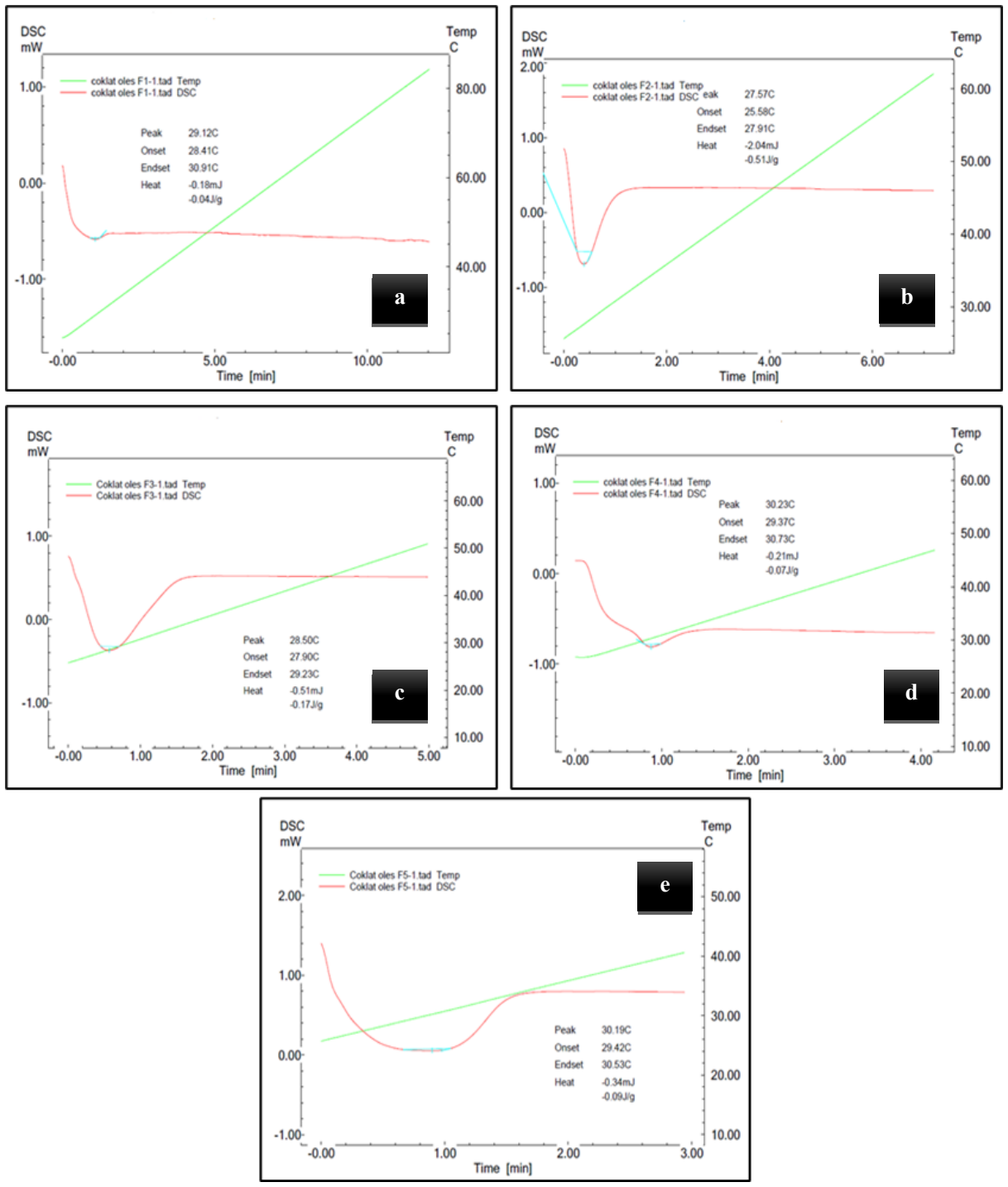

Figure 5. Characterization of melting properties in chocolate spread: a) sample F1 (control); b) sample F2; c) sample F3; d) sample F4; and e) sample F5 
typical chromatogram is shown in Figure 6.

GC-MS results (Figure 6) showing the presence of sixty peaks and components in the sample F5 chocolate spread. Major compounds quantified included: 2.3 butanediol (27.74\%), 2-Furanmethanol (20.58\%), 1,2Propanediol (7.60\%), 4-Cyclopentene-1,2,3-Triol, (1.Alpha.,2.Alpha.,3.Alpha.)

Benzeneacetaldehyde (2.88\%), Decanoic Acid (1.07\%), and Cholest-4-EN-3-OL, (3.BETA.) (0.51\%). Research Afoakwa et al. (2009) reported volatiles, such as butanediol, were also characterised by sweet, honey notes and caramel-like, likely derivatives of Strecker degradation and caramelization reactions developed during cocoa processing and transformed during chocolate flavour synthesis in conching. Heterocyclic compounds including furanmethanol (linalool oxide) were characterised by astringent vinegar notes and fruity -spicy. While the compound Cyclopentene (ketones), Cholest and Decanoic acid as an antioxidant (Singh et al., 2020).

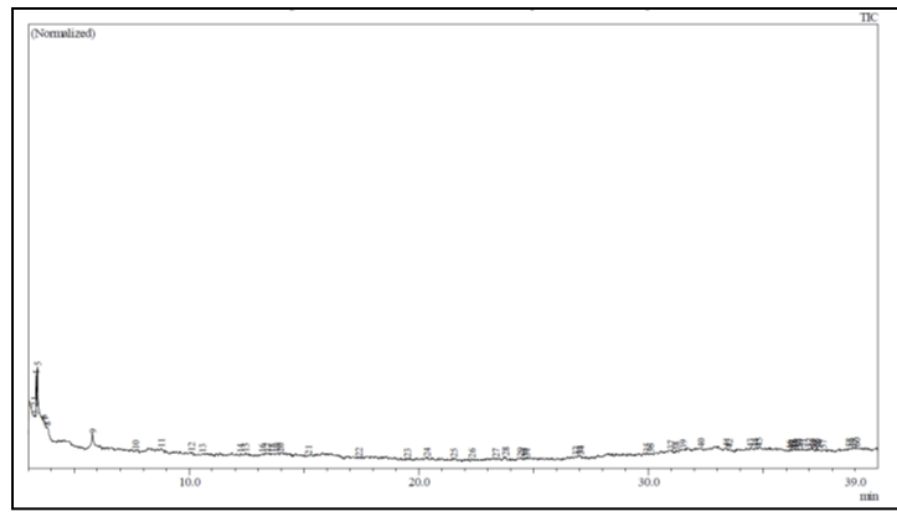

Figure 6. Gas chromatography-mass spectrometry profile chocolate spread in sample F5.

\subsection{Sensory evaluation}

The sensory evaluation of panellists for the jackfruit -chocolate spread samples are as shown in Table 3. Sample F4 (5\% jackfruit flour: $31 \%$ sugar) had the highest preference for taste with a mean rank value of 2.29. The Sample F5 (10\% jackfruit flour: $26 \%$ sugar) and F3 (10\% jackfruit flour: $36 \%$ sugar), with a mean value of 2.61 was the second-highest. The reference sample, F1 (without addition jackfruit flour), with a mean value of 4.19 was the least ranking.

Table 3. Sensory evaluation of chocolate spread samples

\begin{tabular}{cccc}
\hline Sample & Taste & Flavour & Texture \\
\hline F1 & 4.19 & 4.37 & 4.24 \\
F2 & 3.29 & 2.61 & 2.84 \\
F3 & 2.61 & 2.68 & 2.61 \\
F4 & 2.29 & 2.52 & 2.19 \\
F5 & 2.61 & 2.82 & 3.11 \\
\hline
\end{tabular}

Data are represented as mean rank in Friedman test. Means in the same column with the same superscript are significantly different at $(\mathrm{p}<0.05)$.
Similarly, for flavour and texture, the reference sample: F1, had the least value of 4.37 for flavour and 4.24 for texture (Table 3). About flavour, sample F4 had the highest preference with a mean score of 2.52 and sample F2 (5\% jackfruit flour: 36\% sugar) followed as the second highest with a score of 2.61. The textural sensory attribute that describes the smoothness or generally how the sample feels in the palate of the panellist. The sample F4 had the highest preference with a mean score of 2.19 , and sample F3 (10\% jackfruit flour: $36 \%$ sugar) followed as the second highest with a score of 2.61. There were significant differences $(p<0.05)$ amongst panellists' preference for these samples concerning the taste, flavour and texture. This could mean that panellist members could detect any differences in the samples chocolate spreads. From data obtained on the sensory evaluation of samples using the ranking hedonic scale used, chocolate spreads made from jackfruit flour and red palm olein will be accepted when introduced into the market.

\section{Conclusion}

The fortified chocolate spreads showed better emulsion stability and physicochemical characteristics. The formulated chocolate spreads contained relatively higher amounts of polyphenols, carotenoids, antioxidant, low free fatty acid, and better physical attributes (viscosity, colour, $\mathrm{pH}$ and melting point) than the control sample. Chocolate spread samples produced from fortified jackfruit and red palm olein composite were generally liked by a panellist. Jackfruit-red palm olein composite spread gave a better taste, flavour and aroma compared to the reference sample. The fortified jackfruit chocolate spreads could still be accepted by the panellists according to their physical and sensory characteristics. This product when adopted will provide an alternative use for replacing butter fat, but produce chocolate spread with good quality in terms of physicochemical, antioxidant acivity and sensory.

\section{References}

Adan, A.A., Ojwang, R.A., Muge, E.K., Mwanza, B.K. and Nyaboga, E.N. (2020). Phytochemical composition and essential mineral profile, antioxidant and antimicrobial potential of unutilized parts of jackfruit. Food Research, 4(4), 1125-1134. https://doi.org/10.26656/fr.2017.4(4).326

Afoakwa, E.O., Paterson, A. and Fowler, M. (2007). Factors influencing rheological and textural qualities in chocolate - a review. Trends in Food Science and Technology, 18(6), 290-298. https://doi.org/10.1016/ j.tifs.2007.02.002

Afoakwa, E.O., Paterson, A., Fowler, M. and Ryan, A. 
(2009). Matrix effects on flavour volatiles release in dark chocolates varying in particle size distribution and fat content using GC-mass spectrometry and GC -olfactometry. Food Chemistry, 13, 208-215. https:// doi.org/10.1016/j.foodchem.2008.07.088

Afoakwa, E.O., Paterson, A., Fowler, M. and Vieira, J. (2008). Characterization of melting properties in dark chocolates from varying particle size distribution and composition using differential scanning calorimetry. Food Research International, 41(7), 751-757. https://doi.org/10.1016/ j.foodres.2008.05.009

Al-Saqer, J.M., Sidhu, J.S., Al-Hooti, S.N., Al-Amiri, H.A., Al-Othman, A., Al-Haji, L., Ahmed, N., Mansour, I.B. and Minal, J. (2004). Developing functional foods using red palm olein. IV. Tocopherols and tocotrienols. Food Chemistry, 85 (4), 579-583. https://doi.org/10.1016/ j.foodchem.2003.08.003

Almeida, P.F. and Lannes, S.C.D.S. (2017). Effects of chicken by-product gelatin on the physicochemical properties and texture of chocolate spread. Journal of Texture Studies, 48(5), 392-402. https:// doi.org/10.1111/jtxs.12242

Amir, I.Z., Sharon, W.X.R. and Syafiq, A. (2013). Doptimal mixture design on melting and textural properties of dark chocolate as affected by cocoa butter substitution with xanthan gum/guar gum blends. International Food Research Journal, 20(4), 1991-1995.

Andrés-Bello, A., Barreto-Palacios, V., García-Segovia, P., Mir-Bel, J. and Martínez-Monzó, J. (2013). Effect of $\mathrm{pH}$ on Color and Texture of Food Products. Food Engineering Reviews, 5(3), 158-170. https:// doi.org/10.1007/s12393-013-9067-2

AOAC. (2005). Official Methods of Analysis of AOAC International. USA: AOAC.

Baliga, M.S., Shivashankara, A.R., Haniadka, R., Dsouza, J. and Bhat, H.P. (2011). Phytochemistry, nutritional and pharmacological properties of Artocarpus heterophyllus Lam (jackfruit): A review. Food Research International, 44(7), 1800-1811. https://doi.org/10.1016/j.foodres.2011.02.035

Cerit, İ., Şenkaya, S., Tulukoğlu, B., Kurtuluş, M., Seçilmişoğlu, Ü.R. and Demirkol, O. (2016). Enrichment of functional properties of white chocolates with cornelian cherry, spinach and pollen powders. Gida / The Journal of Food, 41(5), 311316. https://doi.org/10.15237/gida.gd16029

de Toledo, N.M.V., Nunes, L.P., da Silva, P.P.M., Spoto, M.H.F. and Canniatti-Brazaca, S.G. (2017). Influence of pineapple, apple and melon by-products on cookies: physicochemical and sensory aspects. International Journal of Food Science and Technology, 52(5), 1-7. https://doi.org/10.1111/ ijfs. 13383

Do, Q.D., Angkawijaya, A.E., Tran-Nguyen, P.L., Huynh, L.H., Soetaredjo, F.E., Ismadji, S. and Ju, Y.H. (2014). Effect of extraction solvent on total phenol content, total flavonoid content, and antioxidant activity of Limnophila aromatica. Journal of Food and Drug Analysis, 22, 296-302. https://doi.org/10.1016/j.jfda.2013.11.001

El-Hadad, N.N.M., Youssef, M.M., Abd El-Aal, M.H. and Abou-Gharbia, H.H. (2011). Utilisation of red palm olein in formulating functional chocolate spread. Food Chemistry, 124(1), 285-290. https:// doi.org/10.1016/j.foodchem.2010.06.034

Fayaz, G., Goli, S.A.H., Kadivar, M., Valoppi, F., Barba, L., Calligaris, S. and Nicoli, M.C. (2017). Potential application of pomegranate seed oil oleogels based on monoglycerides, beeswax and propolis wax as partial substitutes of palm oil in functional chocolate spread. LWT - Food Science and Technology, 86, 523-529. https://doi.org/10.1016/j.lwt.2017.08.036

Gee, P.T. (2007). Analytical characteristics of crude and refined palm oil and fractions. European Journal of Lipid Science and Technology, 109(4), 373-379. https://doi.org/10.1002/ejlt.200600264

Godočiková, L., Ivanišová, E. and Kačániová, M. (2017). The Influence of Fortification of Dark Chocolate with Sea Buckthorn and Mulberry on the Content of Biologically Active Substances. Advanced Research in Life Sciences, 1(1), 26-31. https://doi.org/10.1515/arls-2017-0004

ISO. (2007). Sensory analysis-General guidance for the design of test rooms. 8589. Geneva, Switzerland.

Jeyarani, T., Banerjee, T., Ravi, R. and Krishna, A.G.G. (2013). Omega-3 fatty acids enriched chocolate spreads using soybean and coconut oils. Journal of Food Science and Technology, 52, 1082-1088. https://doi.org/10.1007/s13197-013-1053-4

Komes, D., Belščak-Cvitanović, A., Škrabal, S., Vojvodić, A. and Bušić, A. (2013). The influence of dried fruits enrichment on sensory properties of bitter and milk chocolates and bioactive content of their extracts affected by different solvents. $L W T$ Food Science and Technology, 53(1), 360-369. https://doi.org/10.1016/j.lwt.2013.02.016

Kumar, P. (2015). Process Optimization for the Preparation of Chocolate Spread Incorporating Whey Protein Concentrate, Cocoa Powder, Olive Oil and Butterfat Using Response Surface Methodology. Journal of Food Processing and Preservation, 39(6), 
745-757. https://doi.org/10.1111/jfpp.12284

Loffredo, L., Perri, L., Battaglia, S., Nocella, C., Menichelli, D., Cammisotto, V., Novo, M., Carnevale, R. and Violi, F. (2018). Hazelnut and cocoa spread improves flow-mediated dilatation in smokers. Internal and Emergency Medicine, 13, 1211-1217. https://doi.org/10.1007/s11739-0181913-Z

Manzocco, L., Calligaris, S., Camerin, M., Pizzale, L. and Nicoli, M.C. (2014). Prediction of firmness and physical stability of low-fat chocolate spreads. Journal of Food Engineering, 126, 120-125. https:// doi.org/10.1016/j.jfoodeng.2013.10.042

Mayamol, P.N., Balachandran, C., Samuel, T., Sundaresan, A. and Arumughan, C. (2007). Process technology for the production of micronutrient rich red palm olein. JAOCS, Journal of the American Oil Chemists' Society, 84, 587-596. https:// doi.org/10.1007/s11746-007-1078-9

Ng, S.K., Tan, T.B., Tan, P.F., Chong, G.H. and Tan, C.P. (2019). Effect of high pressure processing on the microbiological, physicochemical and enzymatic properties of jackfruit (Artocarpus heterophyllus L.) bulb. Food Research, 3(3), 213-220. https:// doi.org/10.26656/fr.2017.3(3).208

Prasanth Kumar, P.K., Jeyarani, T. and Gopala Krishna, A.G. (2016). Physicochemical characteristics of phytonutrient retained red palm olein and butter-fat blends and its utilization for formulating chocolate spread. Journal of Food Science and Technology, 53, 3060-3072. https://doi.org/10.1007/s13197-0162279-8

Singh, A., Palariya, D., Dhami, A., Prakash, O., Kumar, R., Rawat, D.S. and Pant, A.K. (2020). Biological activities and Phytochemical analysis of Zanthoxylum armatum DC. leaves and bark extracts collected from Kumaun region, Uttarakhand, India. Journal of Medicinal Herbs and Ethnomedicine, 6, 1 -10. https://doi.org/10.25081/jmhe.2020.v6.5754

Sulistyo, S.B. and Haryanti, P. (2020). Regression analysis for determination of antioxidant activity of coconut sap under various heating temperature and concentration of lysine addition. Food Research, 4 (4), 976-981. https://doi.org/10.26656/fr.2017.4 (4). 410

Sundram, K. (2005). Meeting the Rising Health Awareness : The Palm Oil and Consumer Perception. Palm Oil Developments, 43, 20-28.

Vriesmann, L.C., de Mello Castanho Amboni, R.D. and De Oliveira Petkowicz, C.L. (2011). Cacao pod husks (Theobroma cacao L.): Composition and hotwater-soluble pectins. Industrial Crops and
Products, 34, 1173-1181. https://doi.org/10.1016/ j.indcrop.2011.04.004

Zuwariah, I., Noor Fadilah, M.B., Hadijah, H. and Rodhiah, R. (2018). Comparison of amino acid and chemical composition of jackfruit seed flour treatment. Food Research, 2(6), 539-545. https:// doi.org/10.26656/fr.2017.2(6).106 